\title{
Trade-off Analysis ofEnergy Storage Systems for Helicopter Landing Gear Electromechanical Actuator
}

\author{
Milos Lukic ${ }^{1}$, Paolo Giangrande ${ }^{1}$, Christian Klumpner ${ }^{1}$, Michael Galea ${ }^{2}$ \\ ${ }^{1}$ PEMC, University of Nottingham, Nottingham, United Kingdom \\ ${ }^{2}$ Key Laboratory of More Electric Aircraft Technology of Zhejiang Province, University of Nottingham Ningbo China \\ Milos.Lukic@nottingham.ac.uk
}

\begin{abstract}
The aerospace industry is rapidly changing towards more electric aircraft initiative, trying to alleviate pollution problems and obey the authority bodies' strict rules. Not only should aircraft comply with this initiative but also helicopters (i.e., rotorcrafts), such as the substitution of hydraulic actuators of helicopter landing gear with electromechanical one. Even though this change is a significant step towards full electrification, the next phase would be integrating electromechanical actuators with local energy storage systems resulting in a complete zero-emission actuation. This possibility is rarely investigated in the literature. This paper analyses various electrochemical energy storage devices as an energy source for helicopter landing gear retraction/extension actuation. Lithium-ion batteries, supercapacitor and lithium-ion capacitors are selected as choices for this peculiar application. The trade-off study results show that the best option in terms of weight is storage composed of lithiumion capacitors. In contrast, if the number of extensions and retractions is of the primary concern, the high energy lithium-ion batteries are a preferable choice.
\end{abstract}

Keywords-Batteries, supercapacitors, lithium-ion capacitors, energy storage device.

\section{INTRODUCTION}

In recent years, the aerospace manufacturers have adopted widely accepted approach of more electric aircraft (MEA) [1]. Its main idea of eliminating heavy hydraulic actuators with electro-hydraulic (EHA) and electromechanical (EMA) ones results in significant improvements. For example, the adoption of EHAs for primary flight control surfaces led to $1500 \mathrm{~kg}$ weight reduction on Airbus A380 [2]. Besides primary and secondary flight control surface actuation, electrification of different landing gears (LG) systems and mechanisms have been investigated such as steering, retraction/extension and even taxiing [3]-[5]. Although the helicopters are not exempt from the MEA initiative, the electrification of rotorcraft systems is not as developed as for aircraft. However, many systems have been commercially electrified, such as fuel valve actuation and ejector seat actuator [6]. Furthermore, numerous studies analysed the feasibility and effects of electrification of not yet commercialised systems, for instance, swash-plate control [7] and tail rotor control [8].

All the developed EMAs are powered from the already available power sources onboard the aircraft [9]. This solution is not optimal as the electric energy is produced by the auxiliary power unit (APU) or the main engines by consuming fuel. In addition, the implementation of the needed cables from the fixed

This work is funded by the INNOVATIVE doctoral programme. The INNOVATIVE programme is partially funded by the Marie Curie Initial Training Networks (ITN) action (project number 665468) and partially by the Institute for Aerospace Technology (IAT) at the University of Nottingham. power buses to the remote EMAs increases the onboard distribution system's wiring complexity and is responsible for extra losses and voltage drops. Instead, EMAs could be powered from a local energy storage system (LESS) avoiding the need for excess cabling and use of fuel for powering the actuation. Moreover, as the storage would be localised, the system can be more integrated and compact. Finally, as most actuation processes exhibit regeneration, possible recuperated energy can be saved in a LESS, thus improving the EMA system's efficiency and performance in total [10]. The landing gear (LG) extension is a fundamentally regenerative process, and as such, the LESS for LG retraction/extension actuation is investigated in this paper.

Various categories of energy storages exist nowadays, however, in aerospace applications electrochemical types are the most dominant [11] (e.g., batteries for starting APU and supercapacitors (SCs) for Airbus A380 emergency door opening). Batteries and SCs, as key representatives of this category, are inherently distinctive. The latter ones are characterised by high power densities, current ratings and life cycle with inferior energy density specifications. On the other hand, batteries are more versatile depending on their chemistry. The batteries analysed in this paper are lithium-ion, the state-ofthe-art technology of today. However, also different types of lithium-ion batteries exist based on the material used in cathode and they are namely: nickel manganese cobalt (NMC), nickel cobalt aluminium (NCA) and lithium iron phosphate (LFP). Some of these cells are high energy (HE) cells meaning they are designed to have higher energy density on the expense of having lower power density, where the opposite stands for high power cells (HP). NCA cells are usually HE, LFP cells are typically $\mathrm{HP}$, whereas NMC chemistry is the most flexible and they can be both HE and HP depending on the mass ratio of nickel, manganese, and cobalt. Common for all lithium-ion types is that their energy density is higher and their power density is lower than the supercapacitor's. Another important distinction is that supercapacitors' charge and discharge rates are symmetrical whilst charge rates of batteries are always lower than discharge rates. This means that supercapacitors are more favourable in applications with high possible recoverable energy. Apparently, depending on the application, these two can also work in combination.

In this paper three types of electrochemical energy storages with different chemistry processes, energy and power densities and regeneration capabilities are analysed as a choice for helicopter LG EMA. In section II, the architecture of EMA is introduced, and its operation is explained in detail, including a derivation of power and energy requirements considering the typical drive cycle. Different configurations of lithium-ion batteries, supercapacitors and lithium-ion capacitors with 
associated DC/DC converter are studied in section III. The examined choices are compared in terms of weight, number of extension/retraction cycles etc., and conclusions are derived in section $\mathrm{V}$.

\section{The Helicopter LG EMA Drive Cycle ANALysis}

\section{A. Architecture and operation of the LGEMA}

The role of the EMA under study is to extend and retract the LG of the helicopter, and it is driven by dual-star permanent magnet synchronous machine (PMSM) [12]. Each star is envisaged to be controlled by conventional 2-level voltage source inverter (VSI) connected to the $28 \mathrm{~V}$ DC link. The LG is actuated by applying torque directly to the pivot eliminating the need for a roller screw mechanism and conventional linear actuation of LG. Due to the high load torque requirements $\left(\mathrm{T}_{\text {pivot }}=250 \mathrm{Nm}\right)$, the PMSM is coupled to the pivot through a set of a harmonic drive $\left(\mathrm{N}_{\text {harmonic }}=200 ; \eta_{\text {harmonic }}=0.5\right)$ and spur gear $\left(\mathrm{N}_{\text {spur }}=5 ; \eta_{\text {spur }}=0.5\right)$ [13]. The whole architecture of the EMA is shown in the Fig. 1 (a).

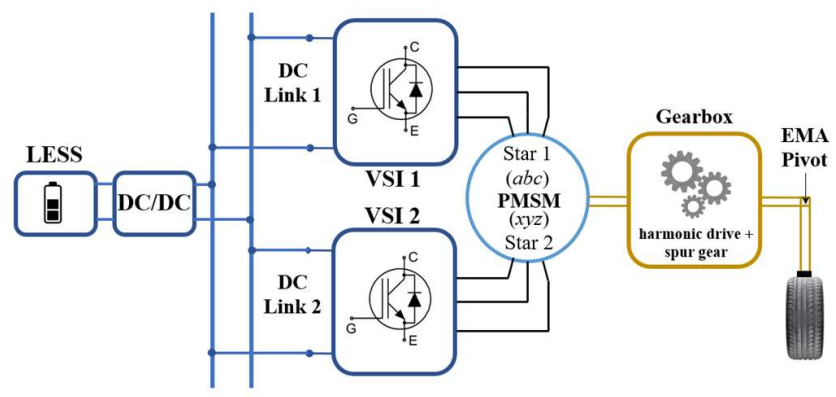

(a)

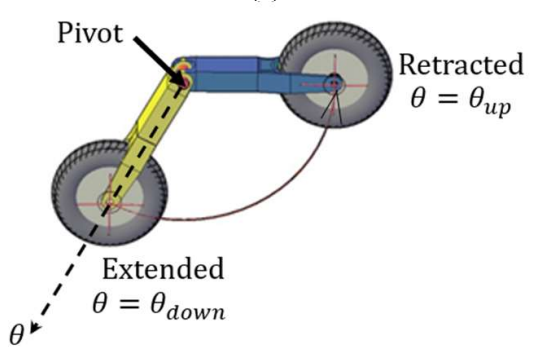

(b)

Fig. 1. (a) The whole architecture of helicopter LG EMA (b) Trajectory of LG during extension and retraction.

When the gear is in the extended position (i.e., down-lock), the angle of the LG is $\theta_{\text {down }}$ which is opposite to the retracted status (i.e., up-lock) when the position of the LG is $\theta_{\text {up }}$ (Fig. 2 (b)). During both retraction and extension, LG should span the arc of $\Delta \theta=\theta_{\text {up }}-\theta_{\text {down }}$ in time interval $\Delta \mathrm{t}_{\mathrm{e} / \mathrm{r}}$. At the beginning of the cycle, the EMA is engaged with the maximum acceleration $\left(\alpha_{\text {pivot,max }}\right)$ for a time span $\Delta \mathrm{t}_{\mathrm{a}}$ until maximum speed $\left(\omega_{\text {pivot,max }}\right)$ is reached. After that, $\omega_{\text {pivot,max }}$ is maintained until $\Delta \mathrm{t}_{\mathrm{e} / \mathrm{r}}-\Delta \mathrm{t}_{\mathrm{a}}$ after which maximum deceleration $\left(-\alpha_{\text {pivot,max }}\right)$ is applied. This results in the drive cycle waveforms as depicted in Fig. 2. which are very similar to the duty cycle obtained using minimum time trajectory algorithm [13]. During both extension and retraction, the load torque at the EMA pivot is equal to $\mathrm{T}_{\text {pivot }}$, whereas during lock up and lock down periods is equal to zero, since the LG engages a lock mechanism. The parameters of the drive cycle are shown in Table I.

Table I. Parameters of the EMA drive cycle.
\begin{tabular}{|c|c|}
\hline Parameter & Value \\
\hline$\theta_{\text {down }}[\mathrm{deg}]$ & 0 \\
\hline$\theta_{\text {up }}[\mathrm{deg}]$ & 126 \\
\hline$\alpha_{\text {pivot,max }}\left[\mathrm{deg} / \mathrm{s}^{2}\right]$ & 6 \\
\hline$\omega_{\text {pivot,max }}[\mathrm{deg} / \mathrm{s}]$ & 18 \\
\hline$\Delta \mathrm{t}_{\mathrm{e} / \mathrm{r}}[\mathrm{s}]$ & 10 \\
\hline$\Delta \mathrm{t}_{\mathrm{a}}[\mathrm{s}]=\omega_{\text {pivot,max }} / \alpha_{\text {pivot,max }}[\mathrm{s}]$ & 3 \\
\hline $\mathrm{T}_{\text {pivot }}[\mathrm{Nm}]$ & 250 \\
\hline
\end{tabular}

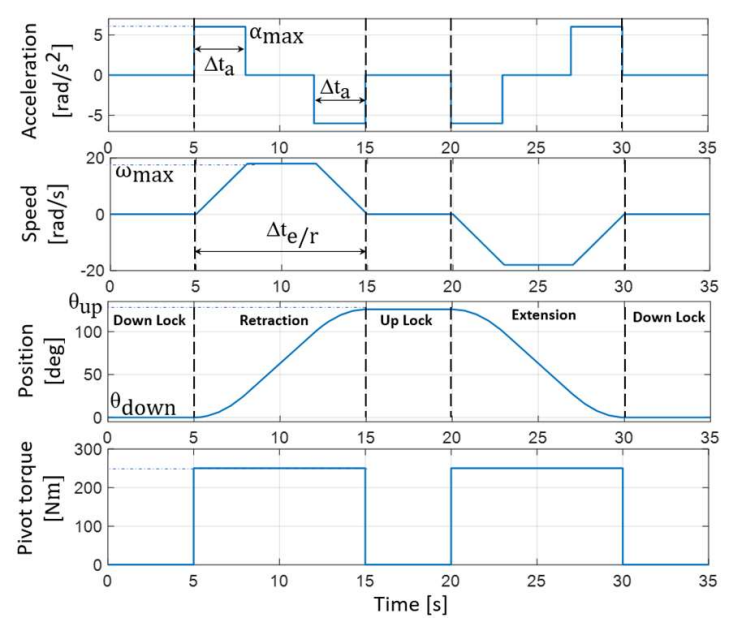

Fig. 2. A typical full drive cycle of LG EMA consisting of retraction and extension.

\section{B. Power and Energy requirements of LESS}

The requirements at the motor shaft are calculated using (1) and (2), using the values from Table I and parameters of the gearbox set.

$$
\begin{gathered}
\omega_{\text {PMSM,shaft }}=\omega_{\text {pivot }} \mathrm{N}_{\text {spur }} \mathrm{N}_{\text {harmonic }}=314.16 \frac{\mathrm{rad}}{\mathrm{s}}=3000 \mathrm{rpm} \\
\mathrm{T}_{\text {PMSM,shaft }}=\frac{\mathrm{T}_{\text {pivot }}}{\mathrm{N}_{\text {spur }} \mathrm{N}_{\text {harmonic }} \eta_{\text {spur }} \eta_{\text {harmonic }}}=1 \mathrm{Nm} \text { (2) }
\end{gathered}
$$

Assuming an efficiency of PMSM and VSI to be 0.9 combined, the power profile at DC link can be calculated from the shaft power and its profile during one extension/retraction full cycle is shown in Fig. 3. The maximum discharge $\left(\mathrm{P}_{\mathrm{dsch}}^{\max }\right)$ and charge $\left(\mathrm{P}_{\mathrm{ch}}^{\max }\right)$ powers that are respectively $350 \mathrm{~W}$ and $285 \mathrm{~W}$. The energy for which the LESS should be sized $\left(E_{\text {req }}\right)$ is proportional to the desired number of full cycles $\left(\mathrm{N}_{\text {cycles }}\right)$ that could be achieved on one charge, i.e., autonomy. Moreover, the $\mathrm{E}_{\text {req }}$ also depends on the regeneration capabilities of the selected type of storage. If $\mathrm{p}$ is defined as the ratio of charging power of storage and $\mathrm{P}_{\mathrm{ch}}^{\max }$, then the $\mathrm{E}_{\mathrm{req}}$ can be calculated using (3).

$$
\mathrm{E}_{\text {req }}[\mathrm{Wh}]=\mathrm{f}\left(\mathrm{N}_{\text {cycles }}, \mathrm{p}\right)=0.68 \mathrm{~N}_{\text {cycles }}+\left(\mathrm{N}_{\text {cycles }}-1\right)\left(0.24 \mathrm{p}^{2}-0.79 \mathrm{p}\right)(3)
$$

For convenience, the $\mathrm{E}_{\text {req }}$ is plotted versus $\mathrm{N}_{\text {cycles }}$ in Fig. 4 for different values of regeneration limit $\mathrm{p}$. It is evident that for 
the given $\mathrm{E}_{\mathrm{req}}$, the LESS that enables $100 \%$ regeneration can provide more cycles on one charge. However, power requirements must also be considered, and in the following section, the LESS is designed for different types that will be connected to the DC link through DC/DC step-up converter.

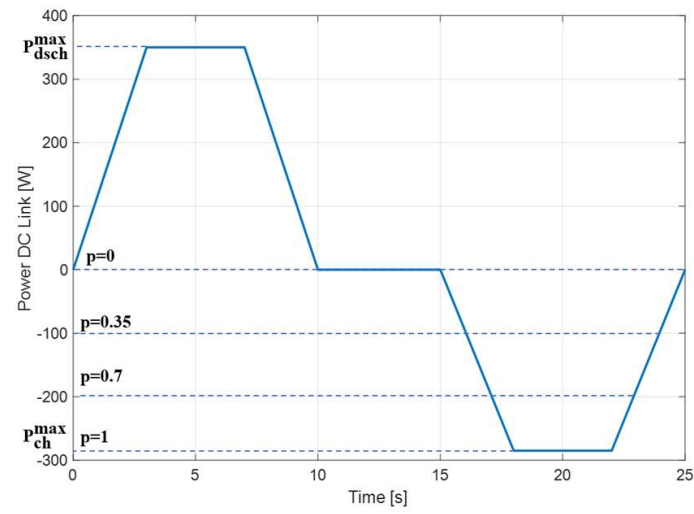

Fig. 3. The power profile of EMA during one full cycle with regeneration limits of the LESS.

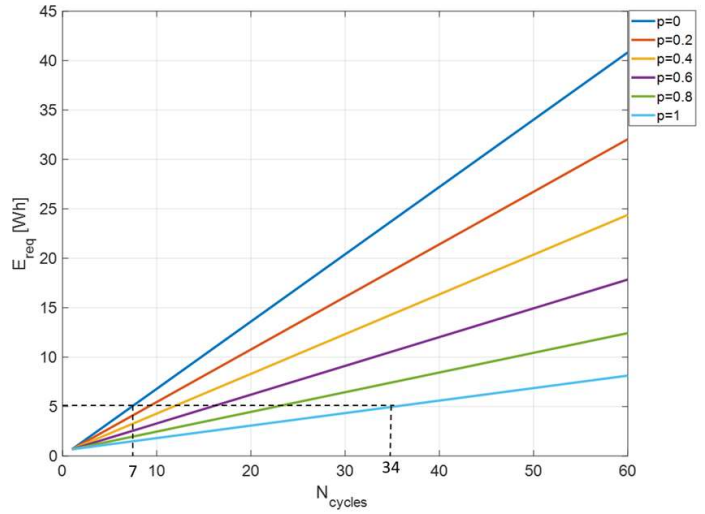

Fig. 4. The energy requirement versus the number of total full cycles $\left(\mathrm{N}_{\text {cycles }}\right)$ and regeneration limit $(\mathrm{p})$

\section{SIZING OF THE LESS}

The sizing of the LESS is carried out considering commercial battery cylindrical cells $(18650,26550)$, supercapacitors (SCs) and lithium-ion capacitors (LiCs). For each selected cell type, the minimum weight LESS is designed that satisfies power requirements $\left(\mathrm{P}_{\mathrm{dsch}}^{\max }=350 \mathrm{~W}\right.$; $\mathrm{P}_{\mathrm{ch}}^{\max }=285 \mathrm{~W}$ ) and DC link voltage of $\mathrm{V}_{\mathrm{DC}}=28 \mathrm{~V}$. Then, the LESS is assessed in terms of autonomy (i.e., energy), weight, in addition to the evaluation of the associated DC/DC converter mass.

\section{A. Battery LESS}

For the battery sizing, the selected manufacturers are Panasonic (NCR), Samsung (INR), LG, Sony (VTC) and A123, the most popular and the most available cell providers on the market. The cells are divided into three categories, namely: 1.) High Energy (HE), 2.) Medium Energy/Power (MEP) and 3.) High Power (HP) and their specifications are shown in Table II. It is noticeable that HE cells have high capacity and energy density but very poor power capabilities. On the other hand, HP cells have very good power density but low energy density and capacity. This is expected as the amount of active material in HP cells is reduced at the cost of the electrode material to increase the power density.

Table II. Selected battery cells for the study

\begin{tabular}{|c|c|c|c|c|c|c|c|c|c|}
\hline & $\begin{array}{c}\mathbf{Q} \\
{[\mathbf{A h}]}\end{array}$ & $\begin{array}{l}\mathbf{V}_{\mathbf{n}} \\
{[\mathbf{V}]}\end{array}$ & $\begin{array}{c}\mathbf{E} \\
{[\mathbf{W h}]}\end{array}$ & $\mathbf{V}_{\min }$ & $\begin{array}{c}\mathbf{m} \\
{[\mathrm{g}]}\end{array}$ & $\begin{array}{c}\mathbf{I}_{\text {cont }}^{\max } \\
{[\mathbf{A}]}\end{array}$ & e $\left[\frac{\mathrm{Wh}}{\mathrm{kg}}\right]$ & $\underset{\left[\frac{\mathrm{kW}}{\mathrm{kg}}\right]}{\mathbf{p}}$ & \\
\hline $\begin{array}{c}\text { LG } \\
\text { MJ1 } \\
\end{array}$ & 3.5 & 3.6 & 12.6 & 2.5 & 49 & 10 & 257.1 & 0.73 & \multirow{4}{*}{$\begin{array}{l}\mathbf{H} \\
\mathbf{E}\end{array}$} \\
\hline $\begin{array}{c}\text { NCR } \\
\text { GA }\end{array}$ & 3.45 & 3.6 & 12.4 & 2.5 & 48 & 10 & 258.7 & 0.75 & \\
\hline $\begin{array}{l}\text { INR } \\
\text { 35E }\end{array}$ & 3.5 & 3.6 & 12.6 & 2.65 & 50 & 8 & 252 & 0.58 & \\
\hline $\begin{array}{c}\text { NCR } \\
\text { B }\end{array}$ & 3.4 & 3.6 & 12.2 & 2.5 & 47.5 & 4.9 & 257.7 & 0.37 & \\
\hline $\begin{array}{c}\text { LG } \\
\text { HG2 }\end{array}$ & 3 & 3.6 & 10.8 & 2.5 & 49 & 20 & 220.4 & 1.47 & \multirow{4}{*}{$\begin{array}{l}\mathbf{M} \\
\mathbf{E} \\
\mathbf{P}\end{array}$} \\
\hline $\begin{array}{c}\text { VTC } \\
6\end{array}$ & 3 & 3.6 & 10.8 & 2 & 46.6 & 15 & 231.8 & 1.16 & \\
\hline $\begin{array}{l}\text { INR } \\
\text { 30Q }\end{array}$ & 3 & 3.6 & 10.8 & 2.5 & 48 & 15 & 225 & 1.13 & \\
\hline $\begin{array}{c}\text { NCR } \\
\text { PF }\end{array}$ & 2.9 & 3.6 & 10.4 & 2.5 & 47.5 & 10 & 219.8 & 0.76 & \\
\hline $\begin{array}{c}\text { LG } \\
\text { HB2 }\end{array}$ & 1.5 & 3.6 & 5.4 & 2.5 & 47 & 30 & 114.9 & 2.3 & \multirow{4}{*}{$\begin{array}{l}\mathbf{H} \\
\mathbf{P}\end{array}$} \\
\hline $\begin{array}{c}\text { VTC } \\
3\end{array}$ & 1.5 & 3.6 & 5.4 & 2.75 & 45.1 & 30 & 119.7 & 2.39 & \\
\hline $\begin{array}{l}\text { INR } \\
20 R \\
\end{array}$ & 2 & 3.6 & 7.2 & 2.5 & 45 & 22 & 160 & 1.76 & \\
\hline A123 & 2.5 & 3.3 & 8.25 & 2 & 76 & 50 & 108.5 & 2.17 & \\
\hline
\end{tabular}

It is evident from Table II and (3) that even the cell with the lowest energy $(5.4 \mathrm{Wh})$ can solely satisfy energy demand for 7.5 cycles. However, that one HP cell cannot alone meet power requirements and thus, more cells should be used either in series or in parallel. Series configuration is preferred to reduce current stresses on the converter, which results in its lower rating and consequently its lower weight. Therefore, as already mentioned, the only design constraints are power requirement (4) and DC link voltage, and the resulting storage is analysed in terms of weight, autonomy, performance etc.

$$
\frac{\mathrm{P}_{\text {dsch }}^{\max }}{\mathrm{N}_{\text {tot,bat }} \mathrm{V}_{\text {min }}}<\mathrm{I}_{\text {cont,bat }}^{\max } \text { (4) }
$$

In (4), $N_{\text {tot,bat }}$ is the total number of cells required to satisfy power prerequisite. It should be noted that batteries are sized considering only the discharge power because charging rates of the selected batteries are very low, i.e., $0.5 \mathrm{C}-1 \mathrm{C}$ (except for A123 cell with 4C). Therefore, they would end up being oversized if designed according to the maximum regenerated power requirement.

The $V_{D C}$ value limits the maximum number of cells in series $\left(\mathrm{N}_{\mathrm{s}, \mathrm{bat}}\right)$ so, whenever $\mathrm{N}_{\text {tot,bat }}$ is greater than $\mathrm{N}_{\mathrm{s}, \mathrm{bat}}^{\mathrm{max}}=7$ the battery pack will have several strings in parallel $\left(\mathrm{N}_{\mathrm{p}, \text { bat }}\right)$. Thus, considering the total number of cells, the battery configuration $\left(\mathrm{N}_{\mathrm{s}, \text { bat }} \mathrm{SN}_{\mathrm{p} \text {,bat }} \mathrm{P}\right)$ is created to maximise the number of cells in series. The sizing results for HE battery are shown in Table III along with its mass, maximum converter current, total energy, the maximum number of cycles considering $80 \%$ depth of discharge and regeneration limit (p). The lightest of all of them is NCR GA with a weight of $672 \mathrm{~g}$, but it also provides the lowest autonomy. 
Table III. Battery specifications sized using HE cells.

\begin{tabular}{|c|c|c|c|c|}
\hline & LG MJ1 & NCR GA & INR 35E & NCR B \\
\hline $\mathrm{N}_{\text {tot }}$ & 14 & 14 & 17 & 29 \\
\hline $\mathrm{xSyP}\left(\mathrm{N}_{\text {tot,real }}\right)$ & $7 \mathrm{~S} 2 \mathrm{P}(14)$ & $7 \mathrm{~S} 2 \mathrm{P}(14)$ & $6 \mathrm{~S} 3 \mathrm{P}(18)$ & $6 \mathrm{~S} 5 \mathrm{P}(30)$ \\
\hline $\mathrm{V}_{\max }-\mathrm{V}_{\min }[\mathrm{V}]$ & $28-17.5$ & $28-17.5$ & $25.2-15.9$ & $25.2-15$ \\
\hline $\mathrm{I}_{\text {string }}^{\max }[\mathrm{A}]$ & 10 & 10 & 7.33 & 4.66 \\
\hline $\mathrm{I}_{\text {converter }}^{\mathrm{max}}[\mathrm{A}]$ & 20 & 20 & 21.99 & 23.33 \\
\hline $\mathrm{E}_{\text {tot }}[\mathrm{Wh}]$ & 176.4 & 173.88 & 226.8 & 367.2 \\
\hline $\mathrm{p}$ & 0.31 & 0.31 & 0.4 & 0.64 \\
\hline $\mathrm{N}_{\text {cycles }}$ & 307 & 303 & 450 & 1086 \\
\hline $\mathrm{m}_{\text {battery }}[\mathrm{g}]$ & $\mathbf{6 8 6}$ & $\mathbf{6 7 2}$ & $\mathbf{9 0 0}$ & $\mathbf{1 4 2 5}$ \\
\hline
\end{tabular}

Similarly, the results for MEP and HP batteries are given in Table IV and Table V, respectively. It can be noticed that HP cells result in the lowest weight and consequently the lowest volume, but also, they are characterised with the lowest number of achievable cycles. As a comparison, the lightest HP battery VTC3 $(225.5 \mathrm{~g})$ is $66 \%$ lighter compared to the most lightweight HE battery, NCR GA. However, 37 cycles of VTC3 are only $12.2 \%$ of the available 303 cycles of NCR GA.

Table IV. Battery specifications sized using MEP cells.

\begin{tabular}{|c|c|c|c|c|}
\hline & LG HG2 & VTC6 & INR 30Q & NCR PF \\
\hline $\mathrm{N}_{\text {tot }}$ & 7 & 12 & 10 & 14 \\
\hline $\mathrm{xSyP}\left(\mathrm{N}_{\text {tot,real }}\right)$ & $7 \mathrm{~S} 1 \mathrm{P}(7)$ & $6 \mathrm{~S} 2 \mathrm{P}(12)$ & $5 \mathrm{~S} 2 \mathrm{P}(10)$ & $7 \mathrm{SP} 2(14)$ \\
\hline $\mathrm{V}_{\max }-\mathrm{V}_{\min }[\mathrm{V}]$ & $28-17.5$ & $25.2-12$ & $21-12.5$ & $28-17.5$ \\
\hline $\mathrm{I}_{\text {string }}^{\max }[\mathrm{A}]$ & 20 & 14.58 & 14 & 10 \\
\hline $\mathrm{I}_{\text {converter }}^{\max }[\mathrm{A}]$ & 20 & 29.17 & 28 & 20 \\
\hline $\mathrm{E}_{\text {tot }}[\mathrm{Wh}]$ & 75.6 & 129.6 & 108 & 146.16 \\
\hline $\mathrm{p}$ & 0.13 & 0.45 & 0.2 & 0.26 \\
\hline $\mathrm{N}_{\text {cycles }}$ & 104 & 279 & 172 & 243 \\
\hline $\mathrm{m}_{\text {battery }}[\mathrm{g}]$ & $\mathbf{3 4 3}$ & 559.2 & 480 & 665 \\
\hline
\end{tabular}

Table V. Battery specifications sized using HP cells.

\begin{tabular}{|c|c|c|c|c|}
\hline & LG HB2 & VTC3 & INR 20R & A123 \\
\hline $\mathrm{N}_{\text {tot }}$ & 5 & 5 & 7 & 4 \\
\hline $\mathrm{xSyP}\left(\mathrm{N}_{\text {tot,real }}\right)$ & $5 \mathrm{~S} 1 \mathrm{P}(5)$ & $5 \mathrm{~S} 1 \mathrm{P}(5)$ & $7 \mathrm{~S} 1 \mathrm{P}(7)$ & $4 \mathrm{~S} 1 \mathrm{P}(4)$ \\
\hline $\mathrm{V}_{\text {max }}-\mathrm{V}_{\min }[\mathrm{V}]$ & $21-12.5$ & $21-13.7$ & $28-17.5$ & $14.4-8$ \\
\hline $\mathrm{I}_{\text {string }}^{\mathrm{max}}[\mathrm{A}]$ & 28 & 25.45 & 20 & 43.75 \\
\hline $\mathrm{I}_{\text {converter }}^{\mathrm{max}}[\mathrm{A}]$ & 28 & 25.45 & 20 & 43.75 \\
\hline $\mathrm{E}_{\text {tot }}[\mathrm{Wh}]$ & 27 & 27 & 50.4 & 33 \\
\hline $\mathrm{p}$ & 0.047 & 0.095 & 0.088 & $0.23-0.46$ \\
\hline $\mathrm{N}_{\text {cycles }}$ & 33 & 37 & 66 & $51-70$ \\
\hline $\mathrm{m}_{\text {battery }}[\mathrm{g}]$ & 235 & $\mathbf{2 2 5 . 5}$ & 315 & 304 \\
\hline
\end{tabular}

Nonetheless, to evaluate the LESS combinations fairly, the weight of the boost converter must be assessed. In other words, its inductor must be designed as it represents the heaviest part of the converter [14]. The value of inductor in (5) is determined such that the input current ripple is less than $\Delta \mathrm{i}_{\mathrm{L}}$ for all operating conditions.

$$
\frac{\mathrm{V}_{\mathrm{DC}}(1-\mathrm{D}) \mathrm{D}}{\mathrm{Lf}}<\Delta \mathrm{i}_{\mathrm{L}}
$$

In the following calculations, $\Delta \mathrm{i}_{\mathrm{L}}$ is selected to be $40 \%$ of the maximum converter current ( $\mathrm{I}_{\text {converter }}^{\mathrm{max}}$ ) with switching frequency of $\mathrm{f}=50 \mathrm{kHz}$. It is evident from (5) that inductance varies for different duty cycles. Over the whole duty cycle range, the inductance reaches its maximum for $\mathrm{D}=0.5$ (Fig. 5). However, sometimes the expected duty cycle range does not span $\mathrm{D}=0.5$ (e.g., $\mathrm{D} \in(0.2,0.4)$ or $\mathrm{D} \in(0.6,0.8))$ and thus, $\mathrm{D}_{\text {critical }}$ is established for a given range, and inductance is calculated using that critical duty cycle (Fig. 5). The actual inductor mass is estimated considering Kool $\mathrm{M} \mu{ }^{\circledR}$ cores using their inductor calculator tool [15]. The results for all three battery types are shown in Table VI.

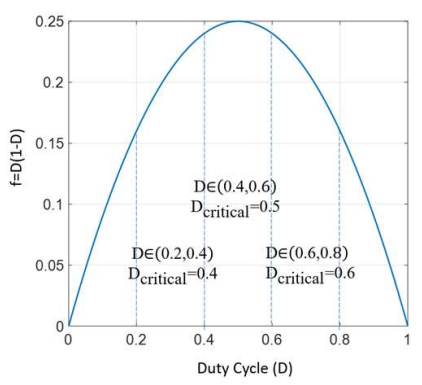

Fig. 5. Inductance variation and $D_{\text {critical }}$.

Table VI. Converter parameters for HE, MEP and HP batteries

\begin{tabular}{|c|c|c|c|c|}
\hline $\mathrm{HE}$ & LG MJ1 & NCR GA & INR 35E & NCR B \\
\hline $\mathrm{D}_{\max }, \mathrm{D}_{\min }$ & $0.375-0$ & $0.375-0$ & $0.43-0.1$ & $0.46-0.1$ \\
\hline $\mathrm{D}_{\text {critical }}$ & 0.375 & 0.375 & 0.43 & 0.46 \\
\hline$\Delta \mathrm{i}_{\mathrm{L}}[\mathrm{A}]$ & 8 & 8 & 8.8 & 9.33 \\
\hline $\mathrm{L}[\mu \mathrm{H}]$ & 16.4 & 16.4 & 15.6 & 14.9 \\
\hline $\mathrm{l}_{\mathrm{Cu}}[\mathrm{mm}]$ & 950.3 & 950.3 & 972.1 & 1078.3 \\
\hline AWG & 11 & 11 & 10 & 10 \\
\hline $\mathrm{m}_{\mathrm{Cu}}[\mathrm{g}]$ & 35.24 & 35.24 & 46.44 & 51.51 \\
\hline $\mathrm{m}_{\text {conv }}[\mathrm{g}]$ & 107.24 & 107.24 & 118.44 & 123.51 \\
\hline $\mathbf{m}_{\text {tot }}[\mathbf{g}]$ & 793.24 & 779.24 & 1018.44 & 1548.51 \\
\hline MEP & LG HG2 & VTC6 & INR 30Q & NCR PF \\
\hline $\mathrm{D}_{\max }, \mathrm{D}_{\min }$ & $0.375-0$ & $0.57-0.1$ & $0.55-0.25$ & $0.375-0$ \\
\hline $\mathrm{D}_{\text {critical }}$ & 0.375 & 0.5 & 0.5 & 0.375 \\
\hline$\Delta \mathrm{i}_{\mathrm{L}}[\mathrm{A}]$ & 8 & 11.67 & 11.2 & 8 \\
\hline $\mathrm{L}[\mu \mathrm{H}]$ & 16.4 & 12 & 12.5 & 16.4 \\
\hline $\mathrm{l}_{\mathrm{Cu}}[\mathrm{mm}]$ & 950.3 & 1052 & 1052 & 950.3 \\
\hline AWG & 11 & 9 & 9 & 11 \\
\hline $\mathrm{m}_{\mathrm{Cu}}[\mathrm{g}]$ & 35.24 & 62.02 & 62.02 & 35.24 \\
\hline $\mathrm{m}_{\text {conv }}[\mathrm{g}]$ & 107.24 & 134.02 & 134.02 & 107.24 \\
\hline $\mathbf{m}_{\text {tot }}[\mathbf{g}]$ & 450.24 & 693.22 & 614.02 & 772.24 \\
\hline $\mathrm{HP}$ & LG HB2 & VTC3 & INR 20R & A123 \\
\hline $\mathrm{D}_{\max }, \mathrm{D}_{\min }$ & $0.55-0.25$ & $0.51-0.25$ & $0.375-0$ & $0.71-0.48$ \\
\hline $\mathrm{D}_{\text {critical }}$ & 0.5 & 0.5 & 0.375 & 0.5 \\
\hline$\Delta \mathrm{i}_{\mathrm{L}}[\mathrm{A}]$ & 11.2 & 10.18 & 8 & 17.5 \\
\hline $\mathrm{L}[\mu \mathrm{H}]$ & 12.5 & 13.8 & 16.4 & 8 \\
\hline $\mathrm{l}_{\mathrm{Cu}}[\mathrm{mm}]$ & 1052.5 & 1078.3 & 950.3 & 1005 \\
\hline AWG & 9 & 10 & 11 & 7 \\
\hline $\mathrm{m}_{\mathrm{Cu}}[\mathrm{g}]$ & 62.05 & 51.51 & 66.43 & 93.77 \\
\hline $\mathrm{m}_{\text {conv }}[\mathrm{g}]$ & 134.05 & 123.51 & 138.43 & 201.77 \\
\hline $\mathrm{m}_{\text {tot }}[\mathrm{g}]$ & 369.05 & 359.01 & 453.43 & 505.77 \\
\hline
\end{tabular}

As expected, the current ripple doesn't vary greatly among all three battery types (8A-16.4A), and consequently, inductance doesn't change significantly as well $(12.5 \mu \mathrm{H}-16.4 \mu \mathrm{H})$. Therefore, all cells utilise the same core $\left(00 \mathrm{k} 4317 \mathrm{e} 090 ; \mathrm{m}_{\text {core }}=\right.$ $72 \mathrm{~g}$ ) and the copper weight dictates the difference among converters. The only exception is LFP A123 battery which utilises the heaviest core $\left(00 \mathrm{k} 4020 \mathrm{e} 90 ; \mathrm{m}_{\text {core }}=108 \mathrm{~g}\right)$. Although there is a difference in copper mass, the variation is not significant enough to offset the difference in batteries' weight. Therefore, including converter, the order of lightest battery storage system does not change. In the following section, supercapacitor LESS is investigated as a potential candidate to compete with batteries.

\section{B. Supercapacitor LESS}

Maxwell (Standard, XP and Dura Blue series) and Skeleton SCs, are analysed for this application (total of 31 cells), whose 
datasheet can be found in [16], [17]. All Maxwell cells have a maximum voltage $\left(\mathrm{V}_{\mathrm{SC}}^{\mathrm{max}}\right)$ of $2.7 \mathrm{~V}$ whereas the Skeleton ones have a slightly higher value of $2.85 \mathrm{~V}$. SC maximum stored energy can be calculated using (6). However, SCs are usually discharged only to half of the maximum voltage $\left(\mathrm{V}_{\mathrm{SC}}^{\min }=0.5 \mathrm{~V}_{\mathrm{SC}}^{\max }\right)$ to reduce the maximum current flowing through SC and its associated converter [18]. Therefore, SC cells' usable energy is $75 \%$ of the maximum one, as demonstrated in (7).

$$
\begin{gathered}
\mathrm{E}_{\mathrm{SC}}^{\max }=0.5 \mathrm{CV}_{\mathrm{SC}}^{\max 2}(6) \\
\mathrm{E}_{\mathrm{SC}}^{\text {usable }}=0.5 \mathrm{C}\left(\mathrm{V}_{\mathrm{SC}}^{\max 2}-\mathrm{V}_{\mathrm{SC}}^{\min ^{2}}\right)=0.75 \mathrm{E}_{\mathrm{SC}}^{\max }
\end{gathered}
$$

Considering that the SC bank's required energy is not defined in advance, the approach taken to analyse the SC LESS is the same as for batteries. For each of the selected cell types, a total minimum number of cells is calculated, which is needed to satisfy the power requirement (4). Since the maximum voltage of each $\mathrm{SC}$ cell is either $2.7 \mathrm{~V}$ or $2.85 \mathrm{~V}$, the configurations are limited to 10 cells $\left(\mathrm{N}_{\mathrm{s}, \mathrm{sc}}^{\mathrm{max}}\right)$ in series in order not to violate DC link voltage constraint. This approach yielded seven solutions that satisfy the power requirement, but their energy content is not sufficient even for one full cycle. This occurs for the cells with low capacitance, and therefore those solutions are removed from the analysis. The specifications (i.e., mass and number of cycles) of the rest 24 SC LESS are shown in Fig. 6.

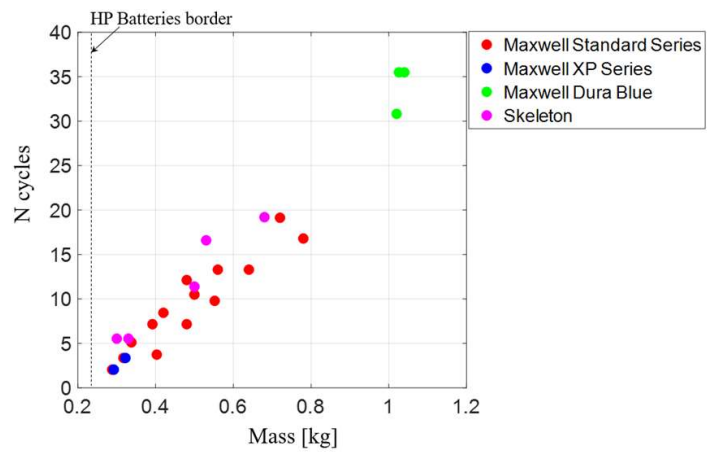

Fig. 6. The SC LESS sized using Maxwell and Skeleton cells.

Interestingly, the possible solutions cover the mass range of all three types of batteries. The heaviest supercapacitors have weight comparable to HE NCR B battery, whereas the lightest SC LESS is $288 \mathrm{~g}$ and it is in the range of upper half of HP battery category (i.e., A123 and INR 20R). However, all SC solutions are heavier than its competitor, VTC3 battery. Moreover, from the autonomy point of view, only Maxwell Dura Blue have a number of cycles comparable to HP battery category but with the weight of more than $1 \mathrm{~kg}$, whilst the lightest options can perform only two full cycles. Considering that none of the solutions is close to lower half of HP batteries in terms of performance and mass, the $\mathrm{DC} / \mathrm{DC}$ converter analysis is not performed for SC storage type. Therefore, SCs cannot compete with HP battery either from weight or autonomy point of view.

\section{Lithium-ion Capacitor LESS}

LiCs are devices that combine characteristics of batteries and supercapacitors in one solitary cell. One electrode of LiC is supercapacitor alike (i.e., active carbon) whereas the other electrode is graphene doped with lithium $\left(\mathrm{LiC}_{6}\right.$, i.e., the anode of battery cells). Nonetheless, the device practically behaves as $\mathrm{SC}$ with higher voltage window $\left(\mathrm{V}_{\mathrm{LiC}}^{\max }=3.8 \mathrm{~V} ; \mathrm{V}_{\mathrm{LiC}}^{\min }=2.2 \mathrm{~V}\right)$. Although this voltage window results in usable energy which is $66 \%$ of its maximum stored energy, LiCs can hold $74 \%$ more energy than SCs for the same capacitance. Furthermore, higher minimum voltage leads to a lower maximum current which, as an impact has lower DC/DC converter weight compared to SCs. Thus, this storage type is also studied as a potential candidate that can alleviate problems of SC LESS.

For this analysis MicroJSB ULTIMO (3 cells) [19] and LICAP (3 cells) [20] LiCs are selected. This storage type is sized using the same approach as in previous sections, with $\mathrm{N}_{\mathrm{s}, \mathrm{LiC}}^{\max }=7$ and requirement (4). The storage configurations and the number of achievable cycles for the minimum weight $\mathrm{LiC}$ LESS of the six selected cell types are shown in Fig. 7. It can be noticed that three combinations exhibit weights that are lower or comparable to the lowest mass limit of HP batteries, and they are namely: 1S1P ULTIMO 1100F, 5S1P LICAP 200F and 2S1P LICAP 800F. Moreover, combinations 6S1P and 7S1P of LICAP 200F also have mass lower than VTC3 battery. However, the 1S1P ULTIMO 1100F solution is disregarded due to the highly inefficient voltage range in which the DC/DC converter would operate. Therefore, the characteristics of $4 \mathrm{LiC}$ LESS that will be further investigated are shown in Table VII.

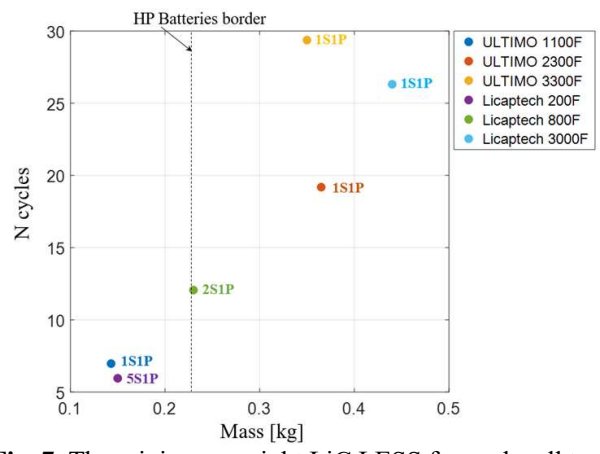

Fig. 7. The minimum weight LiC LESS for each cell type.

\begin{tabular}{|c|c|c|c|c|}
\hline & $200 \mathrm{~F} \mathrm{~N}_{\mathrm{s}}=5$ & $200 \mathrm{~F} \mathrm{~N}_{\mathrm{s}}=6$ & $200 \mathrm{~F} \mathrm{~N}_{\mathrm{s}}=7$ & $800 \mathrm{~F} \mathrm{~N}_{\mathrm{s}}=2$ \\
\hline $\mathrm{E}$ [Wh] & 1.32 & 1.59 & 1.85 & 2.12 \\
\hline $\mathrm{m}_{\mathrm{LiC}}[\mathrm{g}]$ & 150 & 180 & 210 & 230 \\
\hline $\mathrm{N}_{\text {cycles }}$ & 6 & 8 & 10 & 12 \\
\hline $\mathrm{V}_{\max }-\mathrm{V}_{\min }$ & $19-11$ & $22.8-13.2$ & $26.6-15.4$ & $7.6-4.4$ \\
\hline $\mathrm{I}_{\text {max,converter }}$ & 31.81 & 26.52 & 22.72 & 79.54 \\
\hline
\end{tabular}

Table VII. LiC sized using 200F and 800F LICAP cells.

As it can be observed, the lightest device is only $150 \mathrm{~g}$ which is $33 \%$ less compared to VTC3 battery $(223.5 \mathrm{~g})$. This shows possible significant weight savings when using LiCs. Similarly, the converter weight is assessed, and the results are shown in Table VIII. It is evident that added converter reduces the mass margin between LiCs LESS, and the lightest device uses 6 LICAP 200F cells in series, weighing $307.5 \mathrm{~g}$. 
Table VIII. Converter parameters for LESS sized using LiCs.

\begin{tabular}{|c|c|c|c|c|}
\hline & $200 \mathrm{~F} \mathrm{~N} \mathrm{~N}_{\mathrm{s}}=5$ & $200 \mathrm{~F} \mathrm{~N} \mathrm{~s}_{\mathrm{s}}=6$ & $200 \mathrm{~F} \mathrm{~N}_{\mathrm{s}}=7$ & $800 \mathrm{~F} \mathrm{~N}_{\mathrm{s}}=2$ \\
\hline $\mathrm{D}_{\max }, \mathrm{D}_{\min }$ & $0.61-0.32$ & $0.53-0.18$ & $0.45-0.05$ & $0.84-0.73$ \\
\hline $\mathrm{D}_{\text {critical }}$ & 0.5 & 0.5 & 0.45 & 0.73 \\
\hline$\Delta \mathrm{i}_{\mathrm{L}}[\mathrm{A}]$ & 12.72 & 10.61 & 9.09 & 31.81 \\
\hline $\mathrm{L}[\mu \mathrm{H}]$ & 11.2 & 13.2 & 15.24 & 3.47 \\
\hline Core & $\mathrm{k} 4020 \mathrm{e} 090$ & $\mathrm{k} 4317 \mathrm{e} 090$ & $\mathrm{k} 4317 \mathrm{e} 090$ & $\mathrm{k} 4022 \mathrm{e} 090$ \\
\hline $\mathrm{m}_{\text {core }}[\mathrm{g}]$ & 108 & 72 & 72 & 138 \\
\hline $\mathrm{l}_{\mathrm{Cu}}[\mathrm{mm}]$ & 935.6 & 941.3 & 1078.3 & 574 \\
\hline $\mathrm{AWG}$ & 9 & 9 & 10 & 6 \\
\hline $\mathrm{m}_{\mathrm{Cu}}[\mathrm{g}]$ & 55.16 & 55.5 & 51.51 & 67.86 \\
\hline $\mathrm{m}_{\text {conv }}[\mathrm{g}]$ & 163.16 & $\mathbf{1 2 7 . 5}$ & 123.51 & 205.86 \\
\hline $\mathbf{m}_{\text {tot }}[\mathrm{g}]$ & $\mathbf{3 1 3 . 1 6}$ & $\mathbf{3 0 7 . 5}$ & $\mathbf{3 3 3 . 5 1}$ & $\mathbf{4 3 5 . 8 6}$ \\
\hline
\end{tabular}

Comparing to HP battery LESS, the converter weight is higher due to higher maximum current of LiC storage. However, it doesn't offset the weight savings obtained using LiCs. Three LiCs options are still lighter than VTC3 HP solution, with lightest one being $50 \mathrm{~g}$ lighter or $14.7 \%$ lighter than its competitor. Even though the savings in weight might appear not promising, the LiCs have other advantages compared to batteries, which are discussed in the next section.

\section{DISCUSSION AND CONCLSUION}

In this paper three types of electrochemical energy storages (lithium-ion batteries, supercapacitors, and lithium-ion capacitors) were investigated for helicopter LG extension/retraction EMA application. The trade-off study has shown that the best solution, in terms of weight, is storage composed of six $200 \mathrm{~F} \mathrm{LiC} \mathrm{cells} \mathrm{connected} \mathrm{in} \mathrm{series} \mathrm{weighing}$ only $307.5 \mathrm{~g}$, including DC/DC converter. In general, both HP battery and LiC solutions span comparable weight range (359g$453 \mathrm{~g})$ and $(307.5 \mathrm{~g}-435.9 \mathrm{~g})$ respectively, and both having lower weights than other storage types. However, there are major distinctions between these two types. First, using 27Wh HP VTC3 battery results in 37 cycles compared to $1.85 \mathrm{Wh} 200 \mathrm{~F}$ LICAP LiC storage of 8 cycles. As a result, this means that LICAP LiC provides 37 cycles after almost four charging patterns, i.e., using only $7.4 \mathrm{Wh}$ which means it is more energy efficient as it can store all the possible regenerated energy compared to VTC3 battery with only $9.5 \%$ regeneration capability. Furthermore, LiCs have faster charging times and a higher life cycle. Finally, as supercapacitor alike, the control of LiCs storage is inherently easier compared to batteries.

On the other hand, if autonomy is the main concern, the obvious choice would be HE batteries. For every added $1 \mathrm{~g}$ of HE storage, the number of cycles increases by 0.45 compared to 0.16 cycles/g for HP batteries. However, it is arguable if this application's autonomy should be high as 300 cycles and more. Considering that typical helicopter makes around 30 cycles per day, the HE batteries could provide at least 1.5 weeks without charging. In case of LiCs LESS, the device would be charged after every few flights which should not represent a problem as the charging times of LiC type would be around minute compared to hours for batteries. However, the implementation of HE batteries can be justified if they will have a multipurpose role, i.e., they can be charged and discharged during flight for other applications.

Finally, the study has revealed that supercapacitors are not a suitable candidate for this application neither from weight nor autonomy perspective and that $\mathrm{LiCs}$ are a preferable option for this application.

\section{REFERENCES}

[1] B. Sarlioglu and C. T. Morris, "More Electric Aircraft: Review, Challenges, and Opportunities for Commercial Transport Aircraft," IEEE Trans. Transp. Electrif., vol. 1, no. 1, pp. 54-64, 2015.

[2] P. Giangrande, A. Al-Timimy, A. Galassini, S. Papadopoulos, M. Degano, and M. Galea, "Design of PMSM for EMA Employed in Secondary Flight Control Systems,” 2018 IEEE Int. Conf. Electr. Syst. Aircraft, Railw. Sh. Propuls. Road Veh. Int. Transp. Electrif. Conf. ESARS-ITEC 2018, 2019.

[3] W. Cao, B. C. Mecrow, G. J. Atkinson, J. W. Bennett, and D. J. Atkinson, "Overview of electric motor technologies used for more electric aircraft (MEA)," IEEE Trans. Ind. Electron., vol. 59, no. 9, pp. 3523-3531, 2012.

[4] I. Chakraborty, D. N. Mavris, M. Emeneth, and A. Schneegans, "An integrated approach to vehicle and subsystem sizing and analysis for novel subsystem architectures,” Proc. Inst. Mech. Eng. Part G J. Aerosp. Eng., vol. 230, no. 3, pp. 496-514, 2016, doi: 10.1177/0954410015594399.

[5] M. Lukic et al., "State of the Art of Electric Taxiing Systems," 2018 IEEE Int. Conf. Electr. Syst. Aircraft, Railw. Sh. Propuls. Road Veh. Int. Transp. Electrif. Conf. ESARS-ITEC 2018, 2019.

[6] Ametek, "Electromechanical Actuators (EMA)." https://www.ametek airtechnology.com/-/media/ametekairtechnology/pdf/electro-mechanicalactuators.pdf?dmc $=1 \&$ la $=$ en\&revision $=179793 \mathrm{c} 3-7104-4165$-a52520a2ed239b5b (accessed Jan. 04, 2021).

[7] L. Papini, P. Connor, C. Patel, L. Empringham, C. Gerada, and P. Wheeler, "Design and testing of electromechanical actuator for aerospace applications," in 2018 25th International Workshop on Electric Drives: Optimisation in Control of Electric Drives, IWED 2018 - Proceedings, 2018, vol. 2018-Janua, pp. 1-6.

[8] Y. ZHANG, C. JIANG, Y. WANG, F. SUN, and H. WANG, "Design and application of an Electric Tail Rotor Drive Control (ETRDC) for helicopters with performance tests," Chinese J. Aeronaut., vol. 31, no. 9, pp. 1894-1901, 2018, doi: 10.1016/j.cja.2018.07.007.

[9] V. Madonna, P. Giangrande, and M. Galea, "Electrical Power Generation in Aircraft: Review, Challenges, and Opportunities," IEEE Trans. Transp. Electrif., vol. 4, no. 3, pp. 646-659, 2018.

[10] M. Lukic, P. Giangrande, A. Hebala, S. Nuzzo, and M. Galea, "Review, Challenges, and Future Developments of Electric Taxiing Systems," IEEE Trans. Transp. Electrif., vol. 5, no. 4, pp. 1441-1457, 2019.

[11] P. Saenger, N. Devillers, K. Deschinkel, M. C. Pera, R. Couturier, and F. Gustin, "Optimisation of Electrical Energy Storage System Sizing for an Accurate Energy Management in an Aircraft," IEEE Trans. Veh. Technol., vol. 66 , no. 7 , pp. 5572-5583, 2017.

[12] C. Sciascera, P. Giangrande, C. Brunson, M. Galea, and C. Gerada, "Optimal design of an electromechanical actuator for aerospace application," in IECON 2015 - 41st Annual Conference of the IEEE Industrial Electronics Society, 2015, pp. 1903-1908.

[13] P. Giangrande, V. Madonna, S. Nuzzo, and M. Galea, "Design of FaultTolerant Dual Three-Phase Winding PMSM for Helicopter Landing Gear EMA," in 2018 IEEE International Conference on Electrical Systems for Aircraft, Railway, Ship Propulsion and Road Vehicles \& International Transportation Electrification Conference (ESARS-ITEC), 2019, pp. 1-6.

[14] A. Fares, C. Klumpner, and M. Rashed, "Design Considerations to Optimise Supercapacitor-based Energy Storage Systems for Aerospace Applications,” in 2018 IEEE Int. Conf. Electr. Syst. Aircraft, Railw. Sh. Propuls. Road Veh. Int. Transp. Electrif. Conf. ESARS-ITEC 2018, 2019, pp. $1-8$.

[15] "Magnetics ${ }^{\circledR} \quad$ Inductor Design." https://www.maginc.com/Design/Design-Tools/Inductor-Design (accessed Jan. 04, 2021).

[16] "Maxwell Ultracapacitor Cells." http://www.maxwell.com/images/documents/ProductMatrix.pdf (accessed Jan. 04, 2020).

[17] "Skeleton Technologies." https://www.skeletontech.com/skelcap-scaultracapacitor-cells (accessed Jan. 04, 2020).

[18] C. Klumpner and M. Rashed, "Design and Evaluation of a Power Converter for an Energy Storage System for Aircrafts," in 2018 IEEE Int. Conf. Electr. Syst. Aircraft, Railw. Sh. Propuls. Road Veh. Int. Transp. Electrif. Conf. ESARS-ITEC 2018, 2019.

[19] "ULTIMO Lithium Ion Capacitor." https://www.musashies.co.jp/en/product/cell/ (accessed Jan. 04, 2020).

[20] "LICAP Technologis product." https://www.licaptech.com/products. 
